\title{
Purification and Properties of Neuraminidase from Vibrio cholerae
}

\author{
By G. L. ADA, E. L. FRENCH* AND P. E. LIND \\ The Walter and Eliza Hall Institute of Medical Research, Royal Melbourne \\ Hospital Post Office, Victoria, Australia
}

(Received 21 October 1960)

\begin{abstract}
SUMMARY
A method is described for the purification of neuraminidase from culture fluids of Vibrio cholerae. Five steps are involved: fractionation with methanol, adsorption to and elution from human red cells, fractionation with ammonium sulphate, chromatography on columns of hydroxyl apatite, crystallization. From $35 \mathrm{l}$. of culture filtrate, an average yield of $21 \%$ of the original enzyme activity was obtained as crystals. The degree of purification was about 5000 fold. Purified neuraminidase possessed $12 \cdot 6 \times 10^{6}$ units of biological activity/mg. dry weight, and gave a value for $E_{280}^{1 \%} \mathrm{~m}_{\mu}$ of 8.96 , measured at $0.025 \%(\mathrm{w} / \mathrm{v})$. Enzyme activity was stimulated by calcium ions and inhibited by ethylenediaminetetra-acetate. In the presence of $0 \cdot 001 \mathrm{M}-\mathrm{CaCl}_{2}$, neuraminidase showed maximum activity at $\mathrm{pH} \mathrm{5 \cdot 6}$. With sialyl lactose as substrate, a value of $1 \cdot 2 \times 10^{-3} \mathrm{M}$ was found for the Michaelis constant. At an enzyme concentration of $0.16 \mu \mathrm{g} . / \mathrm{ml}$., $V_{\max }$ was $0.021 \mu \mathrm{M}$ $N$-acetylneuraminic acid $/ \mathrm{min} . / \mathrm{ml}$. The enzyme was stable when dried from the frozen state and stored under vacuum at $0^{\circ}$. A suspension of crystals in water also retained activity when stored at $0^{\circ}$. Solutions of crystalline neuraminidase showed a small increase in activity when stored at $0^{\circ}$ for several weeks. This effect was greatest at $\mathrm{pH} 6.7$ and 8.5 but was barely detectable at $\mathrm{pH} 4.6$. At $\mathrm{pH} 5.6$ or 6.7 , the enzyme lost about $20 \%$ of its activity over a period of $2 \mathrm{hr}$. at $37^{\circ}$ (concentration $=15 \mu \mathrm{g} . / \mathrm{ml}$.) No proteolytic activity nor $N$-acetylneuraminic acid aldolase activity was detected in the crystalline preparation.
\end{abstract}

\section{INTRODUCTION}

The ability of culture fluids of Vibrio cholerae to render human red cells inagglutinable by influenza virus was first noticed by Burnet, McCrea \& Stone (1946) who described the active principle as the receptor-destroying enzyme (RDE) of V.cholerae. Gottschalk \& Lind (1949) early provided evidence about the chemical activity of RDE but the enzyme was not characterized as a glycosidase until 1956 (Gottschalk, 1956; Heimer \& Meyer, 1956). The enzyme has been termed sialidase (Heimer \& Meyer, 1956) or neuraminidase (Gottschalk 1957) and its action defined as 'the hydrolytic cleavage of the glycosidic bond joining the keto group of $N$-acetylneuraminic acid to D-galactosamine' (Gottschalk 1957).

* Present address : Division of Animal Health, C.S.I.R.O., Animal Health Research Laboratory, Parkville, Victoria, Australia. 
Early work on the purification of the enzyme (Ada \& French, 1950) was hampered by the complex nature of the culture medium and the low enzyme titre obtained. These difficulties were overcome when it was found that addition of $N$-acetylneuraminic acid or certain derivatives to a simple medium greatly stimulated enzyme production (Ada \& French, 1957, 1959 $a$; French \& Ada, 1959). A dialysate of bovine colostrum enriched with glycerol and peptone was found to be a suitable medium for enzyme production (Ada \& French, 1957). Following growth in this medium and subsequent heating to kill the organisms, filtration yielded a crude extract from which it was possible to purify the enzyme (Ada \& French, 1959b). The present paper presents details of the purification procedure and some properties of the crystalline enzyme. The succeeding paper (Pye \& Curtain, 1961) reports some physical properties of the enzyme.

\section{METHODS}

Peptone. Evans bacteriological peptone or Difco proteose peptone no. 1 was used. Glycerol. A.R. quality.

Peptone water. A solution of glycerol $(0.5 \%, \mathrm{v} / \mathrm{v})$ and peptone $(1 \%, \mathrm{w} / \mathrm{v})$ adjusted to $\mathrm{pH} 7 \cdot 4$ with $\mathrm{NaOH}$ and sterilized by autoclaving (15 lb./sq.in.; $20 \mathrm{~min}$.)

Methanol. A preparation labelled 'acetone-free' was found to be satisfactory.

Anti-frothing reagent. Undecanol $(3 \%, \mathrm{v} / \mathrm{v})$ in peanut oil; sterilized by heating for $1 \mathrm{hr}$. at $180^{\circ}$ on 3 successive days.

$E D T A$. Ethylenediaminetetra-acetic acid solution, adjusted to $\mathrm{pH} \cdot \mathbf{4}$ with $\mathrm{NaOH}$.

Hydroxyl apatite. Prepared according to Tiselius, Hjerten \& Levin (1956). This material could be stored at $0-4^{\circ}$ for periods of at least 1 month.

Sialyl lactose. The method of preparation was described by French \& Ada (1959).

Saline. An aqueous solution of $\mathrm{NaCl}(0 \cdot 15 \mathrm{M})$.

Bovine plasma albumin. Fractionation $\mathrm{V}$ prepared by the Armour Laboratories. Phosphate buffers. Phosphate buffers ( $\mathrm{pH} 6 \cdot 8$ ) were prepared by dilution of $\mathrm{M}$ stock solution $\left(0.5 \mathrm{M}-\mathrm{NaH}_{2} \mathrm{PO}_{4} ; 0.5 \mathrm{M}-\mathrm{Na}_{2} \mathrm{HPO}_{4}\right)$.

Tris-maleate buffers. These were prepared by mixing $0 \cdot 1 \mathrm{~m} 2$-amino-2-hydroxymethylpropane-1:3-diol (tris) and 0.1 M-maleic acid solutions.

Estimation of protein concentration. This was generally determined by the method of Lowry, Rosebrough, Farr \& Randall (1951). On some occasions, it was assessed from optical density measurements at $280 \mathrm{~m} \mu$. In certain kinetic studies, a sample of the enzyme solution was dried $\left(100^{\circ}\right)$ and weighed.

Estimation of $\mathrm{N}$-acetylneuraminic acid $(\mathrm{N}-A N A)$. Total $N$-ANA was estimated by the direct Erhlich reaction (Werner \& Odin, 1952). Free $N$-ANA was estimated by the thiobarbituric acid method (Warren, 1959).

Drying of neuraminidase. Samples of the purified enzyme were dried from the frozen state in vacuo in an apparatus described elsewhere (Holden, 1958). We wish to thank Mr H. F. Holden for this courtesy.

\section{Titration of neuraminidase activity}

(a) Biological method. The method used and definition of a unit of enzyme activity has been described elsewhere (French \& Ada, 1959). 
(b) Chemical method. The substrate solution was constituted as follows: sialyl lactose solution $(10 \%, \mathrm{w} / \mathrm{v}), 0.8 \mathrm{ml}$; $\mathrm{CaCl}_{2}$ solution $(0.01 \mathrm{M}), 1.5 \mathrm{ml}$; tris + maleate buffer (pH 5.6) containing $0.05 \%(\mathrm{w} / \mathrm{v})$ bovine plasma albumin, $12.7 \mathrm{ml}$. Samples $\left(0.35 \mathrm{ml}\right.$.) of this were brought to $37 \cdot 1^{\circ}$ and $0.05 \mathrm{ml}$. of enzyme solution added. At appropriate intervals (usually $10 \mathrm{~min}$.), $0 \cdot 1 \mathrm{ml}$. samples were pipetted into tubes containing $0.1 \mathrm{ml}$. water, $0.1 \mathrm{ml}$. of the periodate reagent (Warren, 1959) was added immediately and the amount of liberated $N$-ANA determined. In all experiments, the rate of release of $N$-ANA at zero time was estimated by extrapolation.

\section{Titration of proteolytic activity}

Casein substrate. Defatted casein (0.5 g.) was suspended in water and $0 \cdot 1 \mathrm{~N}$ $\mathrm{NaOH}$ added cautiously until the protein just dissolved (final volume $=100 \mathrm{ml}$.). This solution was dialysed for $16 \mathrm{hr}$. at $0^{\circ}$ against veronal + acetate buffer.

Buffer. $25 \mathrm{ml}$. 0.04 M-sodium barbiturate, $25 \mathrm{ml}$. 0.04 M-sodium acetate, adjusted to $\mathrm{pH} 6.5$ with $\mathrm{N}-\mathrm{HCl}$. Volume brought to $100 \mathrm{ml}$.

Trypsin. A crystalline preparation was dissolved in buffer, dilutions made in buffer and used immediately.

Test. Enzyme solution $(0.1 \mathrm{ml}$.) was added to $1 \mathrm{ml}$. samples of the substrate solution, the solutions mixed and then incubated for $1 \mathrm{hr}$. at $37^{\circ}$. After cooling in ice water, $0.25 \mathrm{ml}$. of $40 \%(\mathrm{w} / \mathrm{v})$ trichloroacetic acid was added, the solutions mixed, kept at $0^{\circ}$ for $15 \mathrm{~min}$. and then centrifuged $\left(2000 \mathrm{~g} ; 15 \mathrm{~min} .0^{\circ}\right)$. The absorption at $280 \mathrm{~m} \mu$ of the clear supernatant liquid was read in $0.5 \mathrm{~cm}$. optical cells.

\section{Titration of $\mathrm{N}-\boldsymbol{A N A}$-aldolase activity}

$\mathrm{N}-\boldsymbol{A N A}$. A crystalline preparation derived from sialyl lactose (French \& Ada, 1959).

$N$-Acetylmannosamine. A crystalline sample kindly provided by Dr S. Roseman.

Test. To $0.2 \mathrm{ml}$. of $N$-ANA solution $(1.7 \%, \mathrm{w} / \mathrm{v})$ was added $0.3 \mathrm{ml}$. of phosphate buffer $(0.01 \mathrm{M} ; \mathrm{pH} 6.8)$ or neuraminidase dissolved in $0.3 \mathrm{ml}$. buffer. One drop of toluene was added, and after removal of $0.15 \mathrm{ml}$. as the zero time sample, the tubes were stoppered and incubated at $37^{\circ}$ for $24 \mathrm{hr}$. The $N$-acetylhexosamine content of the zero time and $24 \mathrm{hr}$. samples was estimated by the method of Reissig, Strominger \& Leloir (1955), with $N$-acetylmannosamine as standard.

\section{Production of neuraminidase}

Organism. The properties, cultivation and storage of the $4 \mathrm{Z}$ strain of Vibrio cholerae were described previously (French \& Ada, 1959). Twenty-four hr. before bulk growth of the organisms, nutrient broth $(100 \mathrm{ml}$.) was inoculated from an agar slope culture and incubated $\left(6 \mathrm{hr} ., 37^{\circ}\right)$. The whole of this culture was used as inoculum for 1 l. peptone water which was then incubated for $16 \mathrm{hr}$. at $37^{\circ}$. The peptone water culture was used as inoculum for the bulk medium (see below).

Preparation of medium. Bovine colostrum (about 6 l.; first milking after parturition) was dialysed (Visking 27/32 tubing) against $35 \mathrm{l}$. water previously saturated with chloroform. Dialysis was carried out at $0-4^{\circ}$ for $8-14$ days in a stainless steel can with a closely fitting lid, the can being briefly shaken each day. The colostrum was then discarded, the clear diffusate warmed to about $45^{\circ}$ and the chloroform 
removed by aeration with sterile air $(2-3 \mathrm{hr}$.). Glycerol was added to a final concentration of $0.75 \%(\mathrm{v} / \mathrm{v})$. Peptone $(360 \mathrm{~g}$.) was dissolved in 11 . of water, the $\mathrm{pH}$ adjusted to about 7 and insoluble material removed by centrifugation. The clear supernatant liquid was added to the colostrum dialysate and adjusted to $\mathrm{pH} \mathbf{7 \cdot 3}$ with $20 \mathrm{M}-\mathrm{NaOH}$. The medium was filtered $\left(0-4^{\circ}\right)$ through sterilizing pads into sterile containers.

Growth of organism. The medium was transferred to a sterile stainless-steel can and warmed to and maintained at $37^{\circ}$. The can was fitted with a transparent lid through which the shaft of a stirrer and an aeration tube passed. The latter was placed so that sterile air emerged under the blades of the stirrer. The medium was inoculated with the peptone water culture of Vibrio cholerae (see above), the stirrer started and air passed through the medium at about $150 \mathrm{l}$./hr. Frothing was controlled by the addition of the anti-frothing preparation. Incubation was continued for about $10 \mathrm{hr}$.

Destruction of organisms and preparation of crude extract. Dry $\mathrm{CaCl}_{2}$ was added to the culture to give a final concentration of $0.5 \%(w / v)$. The organisms usually aggregated during this procedure. After adjustment to $\mathrm{pH} 6.0$ with $10 \mathrm{~N}-\mathrm{HCl}$, the mixture was brought to $56^{\circ}$, maintained at this temperature for $30 \mathrm{~min}$. to kill the organisms, and then cooled $\left(16 \mathrm{hr}\right.$., $\left.0-4^{\circ}\right)$. When the clumped organisms settled out, the clear supernatant liquid was obtained by decantation (the sedimented organisms amounted to about $1 \mathrm{l}$. in volume). Otherwise the organisms were removed by filtration through a pad of filter-aid. For ease of handling, the cleared liquid (supernatant liquid or filtrate) was divided into two portions for the next treatment; one part was stored at $0-4^{\circ}$ in the presence of toluene for $2-3$ days and the other part processed immediately.

\section{Purification procedure}

Methanol fractionation of crude extract. All procedures in this step were carried out at $0-2^{\circ}$. The cleared liquid (above) was adjusted to $\mathrm{pH} 5 \cdot 0$ with $10 \mathrm{~N}-\mathrm{HCl}$. Methanol, precooled to about $-30^{\circ}$, was added during a period of about $5 \mathrm{hr}$. until the concentration reached $60 \%(\mathrm{v} / \mathrm{v})$. The resultant precipitate was allowed to settle during 2 days. Most of the clear supernatant liquid was decanted and discarded. The precipitate was recovered from the rest by centrifugation $(2000 \mathrm{~g}$; $30 \mathrm{~min}$.). Cold water was added to the packed precipitate to give a slush which was then dialysed against several changes of distilled water to remove methanol (2-3 days). The suspension was centrifuged $(2000 \mathrm{~g} ; 30 \mathrm{~min}$.) and the sediment re-extracted once with an equal volume of water. The supernatant liquids were pooled and called 'neuraminidase concentrate'.

Preparation of human red cell eluate. Human blood was collected into Rous and Turner fluid and the cells washed three times with saline. Unless cells were used on the day collected, a considerable degree of haemolysis occurred in this step and increased the difficulty of later purification. The washed red cells were distributed into two equal portions of $200 \mathrm{ml}$., each of which was distributed into centrifuge cups and held at $0-44^{\circ}$. To the 'neuraminidase concentrate' $\left(0-4^{\circ}\right)$ was added $\mathrm{NaCl}$ and $\mathrm{CaCl}_{2}$ to give final concentrations of $0.85 \%$ and $0.1 \%(\mathrm{w} / \mathrm{v})$, respectively. $\mathrm{N}-\mathrm{NaOH}$ was added cautiously until the $\mathrm{pH}$ value reached $8 \cdot 5$. The slight precipitate which formed was immediately removed by centrifugation $(2000 \mathrm{~g} ; 10 \mathrm{~min}$.; 
$\left.0-4^{\circ}\right)$. The clear supernatant liquid was then added to one portion of red cells, stirred for $1 \mathrm{~min}$. and then centrifuged $\left(2000 \mathrm{~g} ; 3 \mathrm{~min}\right.$; $\left.0-4^{\circ}\right)$. The supernatant liquid was removed and immediately added to the other portion of red cells. Mixing and centrifugation was again carried out as above. The extracted fluid (supernatant liquid) was discarded, the red cells pooled and suspended in $400 \mathrm{ml}$. saline containing $0.01 \mathrm{M}$-EDTA and kept at about $20^{\circ}$ for $10 \mathrm{~min}$., with occasional gentle stirring. The suspension was centrifuged $\left(2000 \mathrm{~g} ; 10 \mathrm{~min} . ; 20^{\circ}\right)$ and the supernatant liquid removed. The red cells were re-extracted as above with another $200 \mathrm{ml}$. of EDTA saline. The supernatant liquids were pooled and re-centrifuged (2000 g.; $20 \mathrm{~min}$.; $0-4^{\circ}$ ), yielding a clear slightly pigmented supernatant liquid (red cell eluate).

Ammonium sulphate fractionation. An equal volume of aqueous saturated $\left(\mathrm{NH}_{4}\right)_{2} \mathrm{SO}_{4}(\mathrm{pH} \mathrm{6.5})$ was immediately added to the red cell eluate. After standing for $16 \mathrm{hr}$. at $0-4^{\circ}$, the fine precipitate was recovered by centrifugation (supernatant liquid discarded), resuspended in 5-10 ml. water and dialysed $\left(48 \mathrm{hr} ., 0-4^{\circ}\right.$ ) against $0.1 \mathrm{M}-\mathrm{NaCl}+0.001 \mathrm{M}$-phosphate buffer $(\mathrm{pH} 6.8)$. The dialysed fluid was centrifuged $\left(2000 \mathrm{~g} ; 10 \mathrm{~min}\right.$; $\left.0-4^{\circ}\right)$ and the residue discarded.

Chromatography on hydroxyl apatite. This procedure was carried out at $0-4^{\circ}$. A column $(10 \mathrm{~cm} . \times 1 \cdot 6 \mathrm{~cm}$.) of hydroxyl apatite was prepared and washed well with a solution containing $0 \cdot 1 \mathrm{M}-\mathrm{NaCl}+0.001 \mathrm{M}$-phosphate buffer ( $\mathrm{pH} \mathrm{6.8)}$. The enzyme solution was passed through the column which was then washed with about $20 \mathrm{ml}$. of the above phosphate saline solution. The effluent was discarded and the column developed with a gradient from $0 \cdot 1 \mathrm{M}-\mathrm{NaCl}+0.001 \mathrm{M}$-phosphate buffer (pH 6.8) to $0 \cdot 1 \mathrm{~m}-\mathrm{NaCl}+0.25 \mathrm{~m}$-phosphate buffer $(\mathrm{pH} \mathrm{6.8)}$. The conditions of the gradient were described previously (see Drake, 1955, p. 18, case 4 with $k=2$ and $V 1=40 \mathrm{ml}$.). Under these conditions, the neuraminidase began to elute when about $40 \mathrm{ml}$. had passed through the column. The eluate was collected in a fraction collector $(\mathbf{1} \cdot \mathbf{3}-\mathbf{2} \cdot 0 \mathrm{ml}$. per tube) and the protein concentration in each tube estimated by measuring the absorption at $280 \mathrm{~m} \mu$. When haemolysis in the preceding stage had been slight, one sharp protein peak showing biological activity was obtained. The enzyme content of samples containing protein was estimated. Those samples which showed close agreement between enzyme activity and protein content (see Fig. $1 a$ ) were pooled. When more than one protein peak was present or when the neuraminidase peak trailed very badly, the samples containing most of the enzyme were pooled and again chromatographed as above. In either case, the appropriate tubes were pooled, dialysed against distilled water $\left(48 \mathrm{hr} . ; 0-4^{\circ}\right)$ and dried from the frozen state in vacuo.

Crystallization of neuraminidase. This procedure was carried out at $0-44^{\circ}$. The dried material was dissolved in $1-1.5 \mathrm{ml}$. water and dilute acetic acid added to $\mathrm{pH} \mathbf{5} \cdot \mathbf{0}$. If the solution became opaque, it was clarified by centrifugation. (If too much acetic acid was added, the solution was neutralized with dilute $\mathrm{NH}_{4} \mathrm{OH}$, again dialysed and dried.) The solution was then cautiously brought to about $\mathrm{pH} 4.5$ and rocked gently for 2-3 days. Crystallization was usually achieved by seeding; it was complete after 3 days. The crystals were then washed with water saturated with $\mathrm{CO}_{2}$ and stored in water at $0-4^{\circ}$. They were dissolved by the addition of $0.01 \mathrm{~N}-\mathrm{NH}_{4} \mathrm{OH}$. 


\section{RESULTS}

\section{Production of neuraminidase}

Maximum production of neuraminidase in the culture medium under the conditions described usually occurred within $10 \mathrm{hr}$. In a typical experiment, the titre of enzyme (per $\mathbf{0 . 2 5} \mathrm{ml}$., estimated by the biological method) at different times after the inoculation of the medium was: $6 \mathrm{hr} ., 100 ; 7.5 \mathrm{hr} ., 350 ; 8.5 \mathrm{hr}$., 1300; 9.5 hr., 2400. After heating to kill the organisms, this fluid had a titre of 2200 . In this experiment, most of the sialyl lactose present in the original medium (as estimated by the direct Ehrlich reaction) had been destroyed by $10 \mathrm{hr}$. (see French \& Ada, 1959). Crude extracts from which crystalline neuraminidase has been obtained possessed titres (per $0 \cdot 25 \mathrm{ml}$.) ranging from 1100 to 4000 .

Table 1. Purification of neuraminidase of Vibrio cholerae

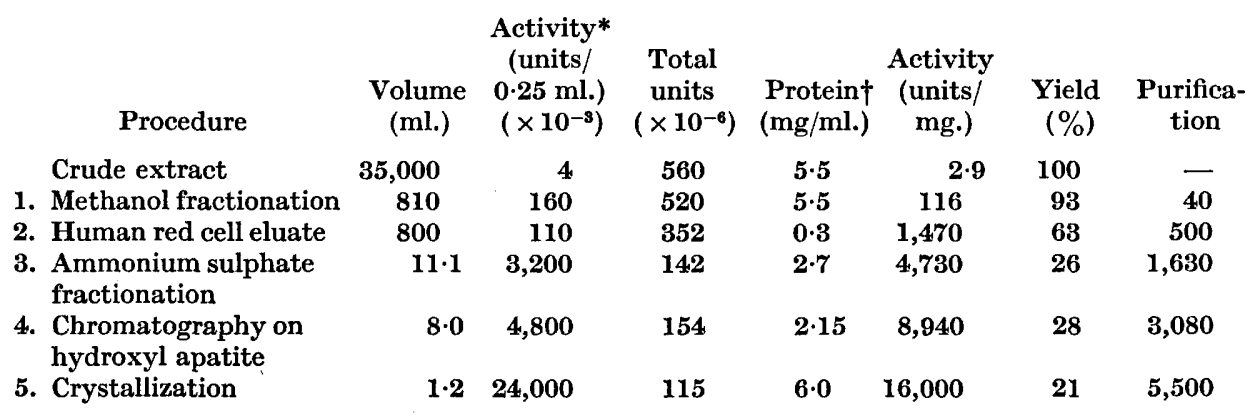

* Estimated by the biological method. At each stage during the purification procedure, samples were diluted $1 / 100$ in calcium acetate broth and stored at $-20^{\circ}$. All enzyme activities were determined on the same day.

$\dagger$ Determined by the method of Lowry et al. (1951), with bovine serum albumin as standard.

\section{Evaluation of purification procedure}

The detailed analysis of the purification procedure as applied to one crude filtrate of a Vibrio cholerae culture is presented in Table 1. Measurements of the volume, enzyme activity and protein content of each fraction allowed an estimate to be made of the yield of pure enzyme and the degree of purification achieved. The major part of the overall purification achieved occurred in the first three steps (methanol fractionation, adsorption to and elution from red cells, ammonium sulphate fractionation). However, the recovery of enzyme was often poor at one or the other of these stages. In the experiment quoted, the major loss of activity occurred during the ammonium sulphate fractionation. Sometimes the greatest loss occurred at the preceding stage of adsorption to and elution from red cells. The low recovery often encountered here was not due to destruction of enzyme; the remaining portion could be accounted for in the fluid after extraction with red cells. In some experiments, a higher recovery of enzyme in the eluate w as obtained by increasing greatly the number of red cells used as absorbent.

Chromatography of the ammonium sulphate precipitate on columns of hydroxyl apatite showed a single protein peak with a very steep leading edge, but the trailing edge varied in steepness from batch to batch. Figure $1 a$ shows the pattern of enzyme 
activity and protein concentration given by the preparation quoted in Table 1 . The close correspondence between enzymic activity (estimated by the biological method) and protein concentration seen at all stages of the peak except the tail end was fairly typical. A protein peak showing a more pronounced trailing edge and thus a greater disparity between protein concentration and enzymic activity was seen occasionally. For example, such a pattern was shown by a preparation in which substantial haemolysis had occurred during elution from red cells. In this case, the most active fractions were pooled and again chromatographed, then yielding a pattern like that shown in Fig. $1 b$.

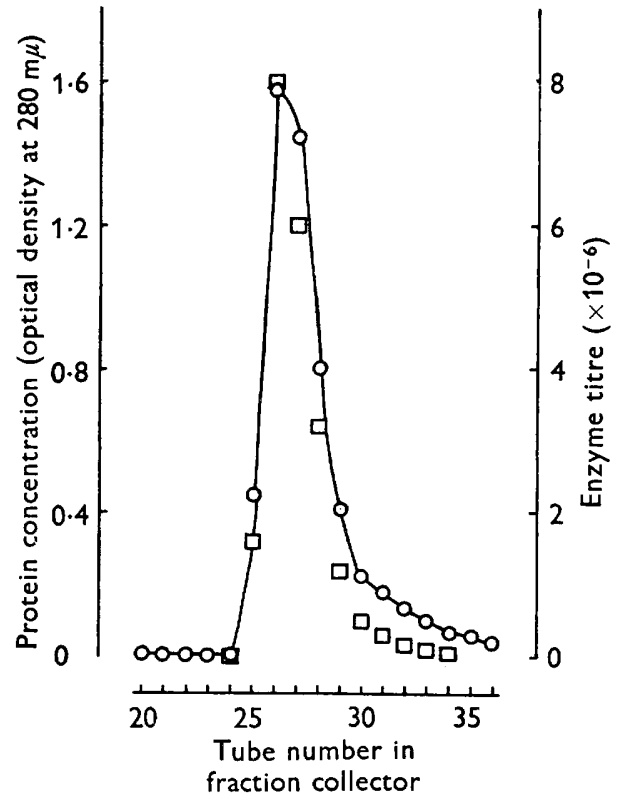

$a$

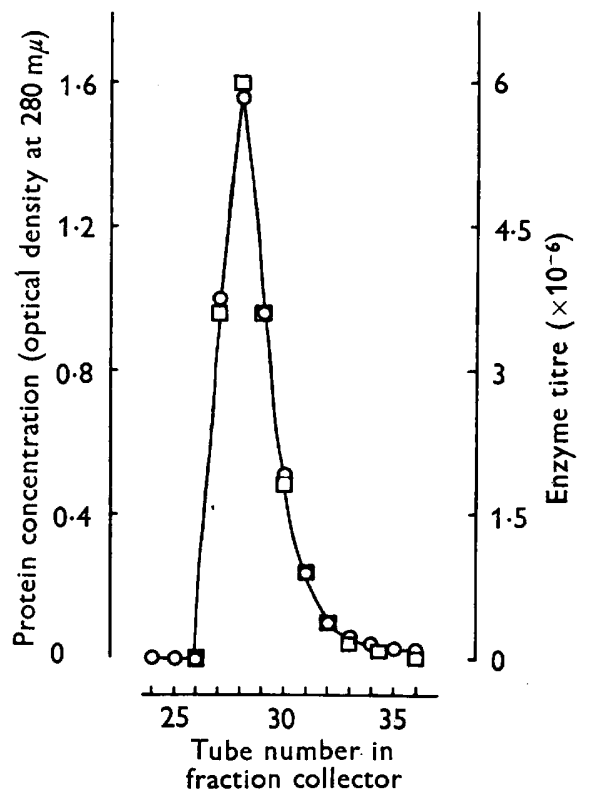

$b$

Fig. 1. Purification of Vibrio cholerae neuraminidase by chromatography on hydroxyl apatite. The elution pattern was obtaned by using a concentration gradient of phosphate buffer (pH 6.8). (a) First chromatographic run. (b) Re-chromatography of pooled selected fractions from first run. Protein concentration, $\mathrm{O}-\mathrm{O}$; enzyme titre, $\square-\square$.

Coloured impurities were removed from the preparation at the chromatography stage so that crystallization was effected from a colourless solution. Crystallization completed the purification procedure. In the experiment quoted, the overall result was a decrease in volume from $35 \mathrm{l}$. to $1.2 \mathrm{ml}$., a yield of $20 \%$ of the original activity as crystals and a $\mathbf{5 5 0 0 - f o l d ~ p u r i f i c a t i o n . ~ N i n e ~ b a t c h e s ~ o f ~ c r y s t a l l i n e ~ e n z y m e ~}$ have been prepared. In six batches, the recovery was estimated and found to vary between 33 and $7 \%$ with a mean value of $21 \%$.

One batch of enzyme behaved differently. The procedure applied differed in one respect from that described above in that the product of methanol fractionation was stored at $-20^{\circ}$ for 14 days. The crude extract had a very high titre (7500), but extensive losses were sustained at each stage of the purification procedure, the 
overall recovery at the ammonium sulphate stage being only $7 \%$. Chromatography on hydroxyl apatite showed a very broad protein peak. No attempt was made to obtain crystals from this batch.

\section{Properties of neuraminidase}

Neuraminidase crystallizes as needles (Pl. 1). Fig. 2 shows the ultraviolet absorption spectrum of the pure enzyme. $E_{280}^{1 \%}$ mas 8.96 , measured at $0.025 \%(\mathrm{w} / \mathrm{v})$. Application of the method of Lowry et al. (1951) for protein estimation to a solution of the enzyme $(0.0152 \%, \mathrm{w} / \mathrm{v})$ yielded an optical density $(0.5 \mathrm{~cm}$. optical cell $)$ of $0 \cdot 194$ at $750 \mathrm{~m} \mu$. The pure enzyme had a biological activity of $12 \cdot 6 \times 10^{6} \mathrm{units} / \mathrm{mg}$. dry weight.

Failure to detect proteolytic activity. Crystalline enzyme $(20 \mu \mathrm{g}$.) failed to show any sign of proteolytic activity against casein at $\mathrm{pH} 6 \cdot 5$; the test could have detected the presence of $0.02 \mu \mathrm{g}$. trypsin.

Failure to detect $\mathrm{N}$ - $A N A$-aldolase activity. Samples of $N$-acetylneuraminic acid ( $N$-ANA; 3.4 mg.) were incubated with buffer or with buffer containing $20 \mu \mathrm{g}$. neuraminidase. After $24 \mathrm{hr}$., less than $15 \mu \mathrm{g}$. of $\mathrm{N}$-acetylmannosamine was detected in either reaction mixture. This corresponds to less than $1 \%$ conversion of $N$-ANA to $\mathrm{N}$-acetylmannosamine.

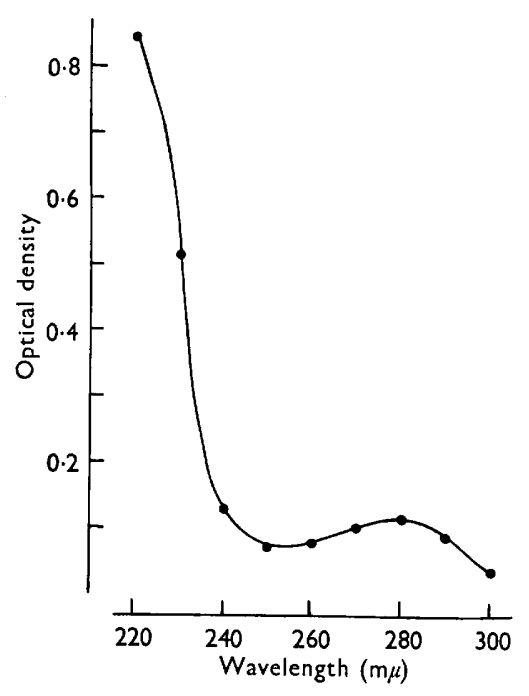

Fig. 2

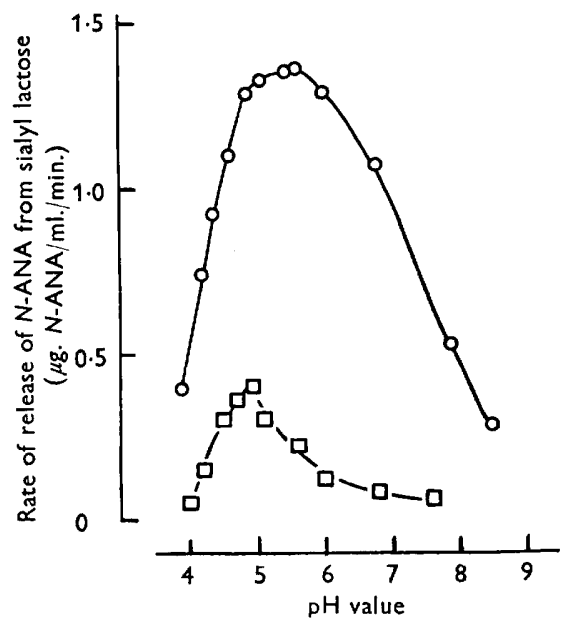

Fig. 3

Fig. 2. Ultraviolet absorption spectrum of Vibrio cholerae neuraminidase. Neuraminidase was dissolved in $0 \cdot 08 \mathrm{M}$-phosphate buffer (pH 6.8). Concentration of enzyme, $0.025 \%(w / v)$.

Fig. 3. The activity of Vibrio cholerae neuraminidase at different pH values. Composition of medium : sialyl lactose, $0 \cdot 17 \%(\mathrm{w} / \mathrm{v})$; buffer $0.3 \mathrm{ml}$., prepared by mixing $0.1 \mathrm{~m}$-tris + 0.1-M maleic acid; neuraminidase, $0.15 \mu \mathrm{g} . / \mathrm{ml}$; ; total volume, $0.4 \mathrm{ml} . \square-\square$, no added $\mathrm{CaCl}_{2} ; \mathrm{O}-\mathrm{O}$, added $\mathrm{CaCl}_{2}(0 \cdot 001 \mathrm{M})$.

\section{Kinetic studies}

Experiments were first carried out to determine the $\mathrm{pH}$ value at which optimum enzyme activity of purified enzyme preparations was shown. The suspension of 
enzyme crystals $\left(0.025 \mathrm{ml}\right.$.) was dissolved in $0.225 \mathrm{ml} .0 .01 \mathrm{~N}-\mathrm{NH}_{4} \mathrm{OH}$ and the volume brought to $1 \mathrm{ml}$. by addition of tris + maleate buffer (pH 4.9). A further dilution into buffers of different $\mathrm{pH}$ values was made shortly before the start of the experiment. Under these conditions, the enzyme showed a maximum activity at $\mathrm{pH} 4.9$ (Fig. 3, lower curve).

Influence of cations on the activity of neuraminidase. Calcium ions were found to stimulate enzyme activity. The results of a typical experiment are shown in Fig. 4, in which the effect of addition of different concentrations of $\mathrm{CaCl}_{2}$ to the enzyme + substrate solutions is illustrated. Maximum stimulation was found at $0.001 \mathrm{M}-\mathrm{CaCl}_{2}$. Stimulation was not observed when the $\mathrm{CaCl}_{2}$ concentration was $0 \cdot 1 \mathrm{M}$.

Enzyme activity was also affected by certain other cations. The chlorides of manganese, magnesium, barium, zinc or sodium were added to the medium to a final concentration of $0.001 \mathrm{M}$. The rate of release of $\mathrm{N}$-ANA from sialyl lactose at $\mathrm{pH} 4.9$ (expressed as $\mu \mathrm{g}$. $\mathrm{N}$-ANA $/ \mathrm{ml}$./min.) was in the presence of $\mathrm{CaCl}_{2}, 2 \cdot 0 ; \mathrm{MnCl}_{2}, \mathbf{1} \cdot \mathbf{0}$; $\mathrm{ZnCl}_{2}, 0 \cdot 7 ; \mathrm{MgCl}_{2}, 0 \cdot 4 ; \mathrm{BaCl}_{2}$ and $\mathrm{NaCl}, 0 \cdot 3$.

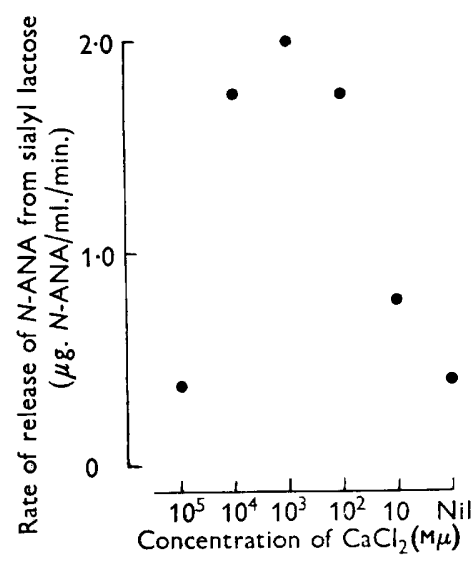

Fig. 4

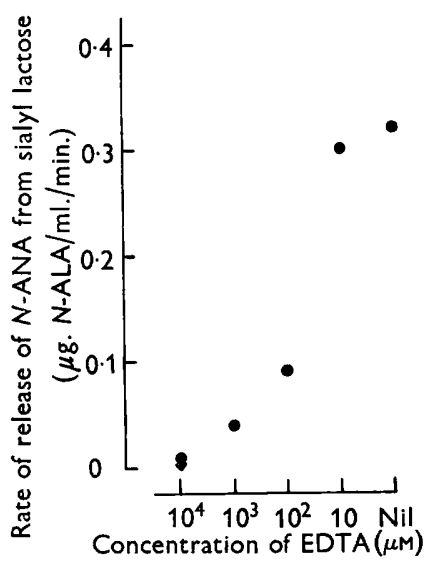

Fig. 5

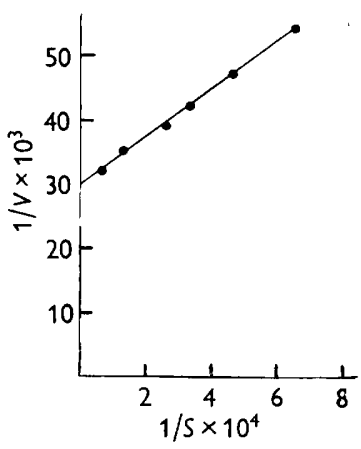

Fig. 6

Fig. 4. The activity of Vibrio cholerae neuraminidase in presence of added $\mathrm{CaCl}_{2}$. Composition of medium: sialyl lactose, $0.17 \%(\mathrm{w} / \mathrm{v})$; tris + maleate buffer, $0.06 \mathrm{M}(\mathrm{pH} 5 \cdot 6)$; neuraminidase, $0 \cdot 27 \mu \mathrm{g} . / \mathrm{ml}$.

Fig. 5. The activity of Vibrio cholerae neuraminidase in the presence of added ethylenediaminetetra-acetate (EDTA). Composition of medium: sialyl lactose, $0 \cdot 17 \%(w / v)$; tris + maleate buffer, $0.06 \mathrm{M}(\mathrm{pH} \mathrm{6.6)}$; neuraminidase, $0.27 \mu \mathrm{g} . / \mathrm{ml}$.

Fig. 6. Activity of Vibrio cholerae neuraminidase as a function of substrate concentration. $\mathrm{S}$ is the concentration (M) of substrate; $\mathrm{V}$ is the velocity of action (plotted on an arbitrary scale).

Inhibition of enzyme activity by ethylenediamine tetra-acetate. In Fig. 5 are plotted the results of one of two experiments to investigate the effect of added EDTA on the activity of neuraminidase. Increasing inhibition of enzyme activity occurred as the concentration of EDTA was raised. In a separate experiment, enzyme (75 $\mu \mathrm{g}$. ml.) was stored in $0.01 \mathrm{M}-\mathrm{EDTA}(\mathrm{pH} \mathrm{5.6})$ for $40 \mathrm{hr}$. at $0-4^{\circ}$. It was then diluted and tested in the presence of $0.001 \mathrm{M}-\mathrm{CaCl}_{2}$ and showed full activity. 
Effect of $\mathrm{pH}$ value on neuraminidase activity. In the presence of $0.001 \mathrm{M}-\mathrm{CaCl}_{2}$ neuraminidase showed maximum activity at $\mathrm{pH} 5 \cdot 6$. Below $\mathrm{pH} 5$ and above $\mathrm{pH} 6$, the activity decreased rapidly (Fig. 3, upper curve).

Enzyme constants. Constants were determined at $37 \cdot 1^{\circ}$ in tris + maleate buffer (pH 5.6; $0.07 \mathrm{M})$ containing $\mathrm{CaCl}_{2}(0.001 \mathrm{M})$, bovine plasma albumin $(0.03 \%)$ and sialyl lactose. A Lineweaver \& Burk (1934) plot of the data yielded a value of $1.2 \times 10^{-3} \mathrm{M}$ for the Michaelis constant $K_{m}$ (Fig. 6). At an enzyme concentration of $0.16 \mu \mathrm{g} . / \mathrm{ml}$., $V_{\max }$ was $0.021 \mu \mathrm{M}-N-\mathrm{ANA} / \mathrm{min} . / \mathrm{ml}$.

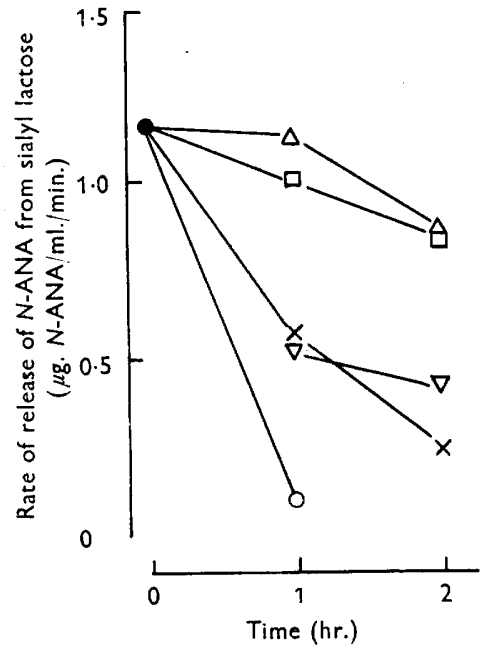

$\boldsymbol{a}$

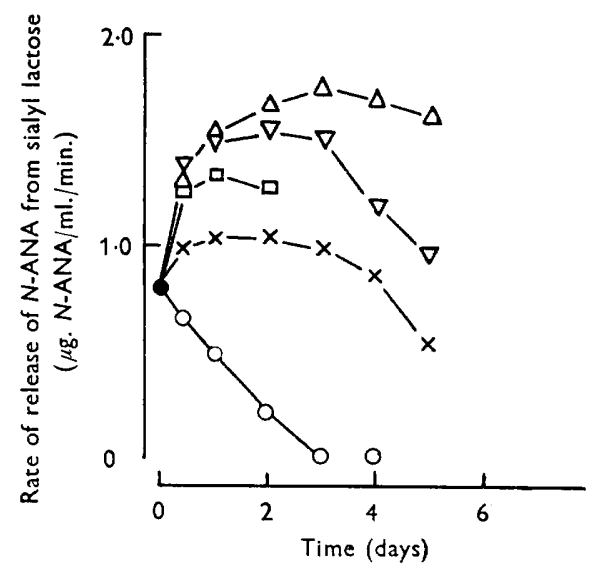

b

Fig. 7. Stability of Vibrio cholerae neuraminidase stored at (a) different $\mathrm{pH}$ values at $37^{\circ}$ and $(b)$ at $0-4^{\circ}$. The activity of the stored enzyme (about $15 \mu \mathrm{g} . / \mathrm{ml}$.) was determined in

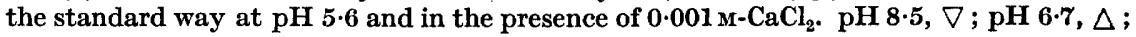
pH 5.6, $\square ; \mathrm{pH} \mathrm{4 \cdot 6, \times ;} \mathrm{pH} \mathrm{3 \cdot 9,} \mathrm{O}$.

\section{Stability of purified neuraminidase}

The stability of neuraminidase in solution was tested at $37^{\circ}$ and $0-4^{\circ}$. Some tests were also carried out on the dry enzyme.

Stability at $37^{\circ}$. Neuraminidase lost activity when incubated at $37^{\circ}$. This was first noticed when estimating the velocity in the chemical test for enzyme activity. For example, the decrease in velocity per min. at different $\mathrm{pH}$ values was as follows: $\mathrm{pH} 4 \cdot 3,0 \cdot 45 \% ; \mathrm{pH} 5 \cdot 0,0 \cdot 4 \%$; $\mathrm{pH} 6 \cdot 2,0 \cdot 3 \% ; \mathrm{pH} 7 \cdot 9,0 \cdot 2 \%$.

To find the $\mathrm{pH}$ value of optimum stability, some crystals were dissolved in $\mathrm{NH}_{4} \mathrm{OH}$ and brought to about $\mathrm{pH} 5 \cdot 6$. Samples $(0 \cdot 1 \mathrm{ml}$.) were added to $0.9 \mathrm{ml}$. volumes of buffer at $\mathrm{pH} 3 \cdot 9,4 \cdot 6,5 \cdot 6,6 \cdot 7$ and $8 \cdot 5$ (final enzyme concentration about $15 \mu \mathrm{g} . / \mathrm{ml}$.). These mixtures were then incubated at $37^{\circ}$ for $1 \mathrm{hr}$; some of the $\mathrm{pH} 5 \cdot 6$ sample was kept at $0^{\circ}$ : Samples from each mixture were then added to a solution of sialyl lactose and $\mathrm{CaCl}_{2}$ buffered at $\mathrm{pH} \mathrm{5.6}$ and the enzyme activities determined. The enzyme solutions, incubated at $37^{\circ}$, had the following activities expressed as a percentage of the control solution kept at $0^{\circ}: \mathrm{pH} 3 \cdot 9,9 \% ; \mathrm{pH} 4 \cdot 6,50 \% ; \mathrm{pH} \mathrm{5.6}$, $112 \% ; \mathrm{pH} 6.7,130 \% ; \mathrm{pH} 8.5,42 \%$. In a second experiment, dissolved enzyme was stored at $0-4^{\circ}\left(\mathrm{pH} 5 \cdot 6\right.$ ) for $18 \mathrm{hr}$. before incubation at $37^{\circ}$. The results of this 
experiment are plotted in Fig. $7 a$. The enzyme was most stable in the range pH $5 \cdot 6-$ $6 \cdot 7$, about $24 \%$ of the activity being lost in $2 \mathrm{hr}$. The enzyme was particularly unstable at $\mathrm{pH}$ 3.9.

Stability at $0-4^{\circ}$. The experimental procedure followed here was similar to that described in the preceding paragraph except that the enzyme solutions (at pH 3.9, $4 \cdot 6,5 \cdot 6,6 \cdot 7,8 \cdot 5)$ were held at $0-4^{\circ}$ for several weeks. At intervals samples were removed and the enzymic activity determined at $\mathrm{pH} \mathbf{5} \cdot 6$. The results are plotted in Fig. $7 b$. The most striking feature was the rise in activity shown by enzyme stored at the higher $\mathrm{pH}$ values. After this initial rise, the activity again slowly decreased.

Stability of dried enzyme. Purified enzyme to be sent to other laboratories was dried from the frozen state in glass ampoules which were then sealed under vacuum. When stored at $0-4{ }^{\circ}$, such material retained nearly full activity (as tested by the biological method) for at least 6 months.

\section{DISCUSSION}

Purification procedure. Several factors have contributed to the successful outcome of this work. In the first place the presence in the medium of sialyl lactose, an inducer of neuraminidase (French \& Ada, 1959), ensured the production of high titres of enzymes. The crude extract thus had a high specific activity (enzyme units/ mg. protein). Secondly, the medium contained only simple ingredients which were not precipitated by $60 \%(\mathrm{v} / \mathrm{v})$ methanol in water at $0^{\circ}$ and this largely accounted for the 40-fold purification achieved in the first step. In addition, the enzyme was concentrated about 40 -fold in this step and thus was contained in a volume small enough to allow rapid extraction with red cells, by using ordinary laboratory facilities.

The process of specific adsorption to and elution from red cells, first introduced by Burnet \& Stone (1947), played an important part in the purification procedure. The recovery rate of this step was about $50 \%$. Attempts to increase the yield of enzyme in the eluate were unsuccessful; increasing the number of red cells used as adsorbent did not always result in improved yields. The use of ethylenediaminetetra-acetic acid at room temperature to effect rapid elution of the enzyme, instead of prolonged incubation of enzyme and red cells at $37^{\circ}$ (Ada \& French, 1950), decreased the contamination of the eluate with red cell breakdown products.

Precipitation of the enzyme with ammonium sulphate was a convenient way of decreasing the volume to be handled and of restoring the protein concentration to a high value which was maintained in the later stages of the process. Although not formally demonstrated, our experience was consisient with the belief that removal of most of the impurities by chromatography on hydroxyl apatite was a prerequisite for a high yield of crystalline enzyme. While the yield of crystalline enzyme was satisfactory there were two stages in the procedure where substantial losses occurred. Experiments in progress may show ways of decreasing these losses.

Properties of the enzyme. No information about the chemical properties of the enzyme is yet available. A preliminary examination of the physical properties is reported in the succeeding paper (Pye \& Curtain, 1961). The results suggested that the crystalline enzyme was homogeneous by the usual physical criteria. 
Sialyl lactose was used as the substrate in kinetic studies for several reasons. It is a well characterized compound, is readily prepared in large amounts, and since it is very soluble, high substrate concentrations can be achieved. However, kinetic constants may vary with the substrate used.

The addition of $\mathrm{Ca}(0.001 \mathrm{M})$ to the reaction medium stimulated neuraminidase activity (cf. Burnet \& Stone, 1947). High concentrations $(0 \cdot 1 \mathrm{M})$ of $\mathrm{Ca}$ did not stimulate activity, a feature which has been noticed with other metal +enzyme systems. The addition of $\mathrm{Ca}$ ion to the medium changed the shape of the $\mathrm{pH}-$ activity curve; the value for optimum activity was displaced from $\mathrm{pH} 4 \cdot 9$ to $\mathrm{pH} \mathrm{5.6.}$ The mode of action of added Ca ion (whether it combined with enzyme or substrate or acted as a link beween enzyme or substrate) remains to be investigated. The activity shown by neuraminidase in the absence of added $\mathrm{Ca}$ ion was inhibited by ethylenediaminetetra-acetic acid which suggests that the enzyme as isolated contained a metal as an essential component.

A puzzling feature of the stability results was the initial increase in activity on storage of the enzyme, particularly at $0 \sim 4^{\circ}$. Here the rise was observed at all $\mathrm{pH}$ values except 3.9 and was greater as the $\mathrm{pH}$ value increased. At the higher values tested ( $\mathrm{pH} 6 \cdot 7,8 \cdot 5$ ) this increase occurred over 3 weeks, reaching a value about double the original. This effect was less clear at $37^{\circ}$. It seems likely that two opposing factors were operating: one was a change of the enzyme to a more active form (disaggregation?), a process favoured by storage of dilute solutions at high $\mathrm{pH}$ values, and the other was thermal inactivation of the enzyme. This finding

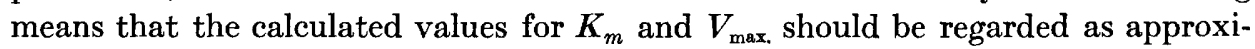
mate rather than absolute. It should also be pointed out that, despite the variation in thermal stability shown by enzyme stored at different $\mathrm{pH}$ values, the curve in Fig. 3 is essentially a true indication of the activity of the enzyme at each $\mathrm{pH}$ value, since velocity values were obtained by extrapolation to zero time.

Schramm \& Mohr (1959) independently published a method for the purification of neuraminidase from Vibrio cholerae cultures. The properties of their preparation are different from those described here. In addition to the low molecular weight $(10,000-20,000)$ they found their preparation was very unstable unless stored in the presence of chelating agents or cyanide. The $K_{m}$ value of their preparation $\left(1-2 \times 10^{-4} \mathrm{M}\right)$ is different from that found with our preparation $\left(1 \cdot 2 \times 10^{-3} \mathrm{M}\right)$ but this might be due to the smaller enzyme molecule and the different substrate used by Schramm \& Mohr (sheep red cells). We cannot as yet offer any experimental evidence which would explain the many differences between the two preparations.

We wish to thank the different organizations, particularly the Victorian Department of Agriculture, who have supplied us with bovine colostrum. The work was supported by the National Health and Medical Research Council, Canberra, Australia. The authors are also indebted to Mr K. Clarke for excellent technical assistance. 
Journal of General Microbiology, Vol. 24, No. 3

Plate 1

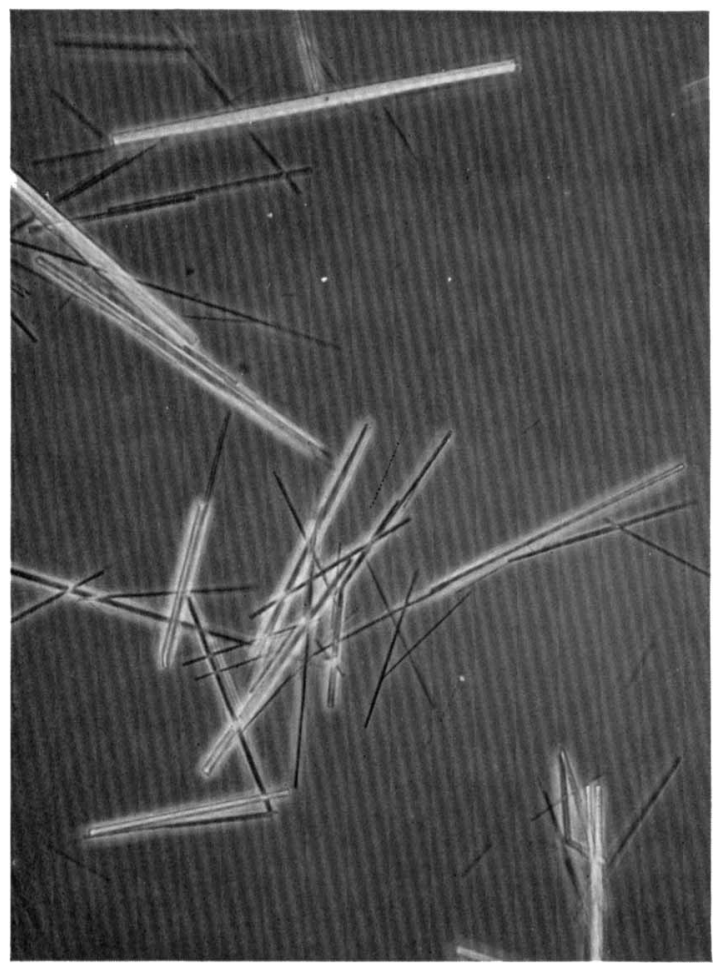

G. I. $\Lambda \mathrm{D} \Lambda$, L. L. FRENCH AND P. L. LINI)

(Facing $p .42 \mathrm{I}$ ) 


\section{REFERENCES}

Ada, G. L. \& French, E. L. (1950). Purification of the receptor destroying enzyme of V. cholerae. Aust. J. Sci. 13, 82.

Ada, G. L. \& French, E. L. (1957). Stimulation of the production of the receptor destroying enzyme (RDE) of $V$. cholerae by neuraminic acid derivatives. Aust. J. Sci. 19, 227.

AdA, G. L. \& French, E. L. $(1959 a)$. Stimulation of the production of neuraminidase in Vibrio cholerae cultures by $N$-acetylmannosamine. J. gen. Microbiol. 21, 561.

Ada, G. L. \& French, E. L. (1959b). Purification of bacterial neuraminidase (receptordestroying enzyme). Nature, Lond. 183, 1740.

Burnet, F. M., McCrea, J. F. \& Stone, J. D. (1946). Modification of human red cells by virus action. I. The receptor gradient for virus action in human red cells. Brit. J. exp. Path. 27, 228.

Burnet, F. M. \& Stone, J. D. (1947). The receptor destroying enzyme of $V$. cholerae. Aust. J. exp. Biol. med. Sci. 25, 227.

Drake, B. (1955). Contributions to the theory of gradient elution analysis. Ark. Kemi, $8,1$.

French, E. L. \& Ada, G. L. (1959). Stimulation of the production of neuraminidase in Vibrio cholerae cultures by $\mathrm{N}$-acetylneuraminic acid and sialyl lactose. J. gen. Microbiol. 21, 550.

Gotrschalk, A. (1956). Neuraminic acid: the functional group of some biologically active mucoproteins. Yale J. Biol. Med. 28, 525.

GotTschalk, A. (1957). Neuraminidase: the specific enzyme of influenza virus and Vibrio cholerae. Biochem. biophys. Acta, 23, 654.

Gotrschalk, A. \& Lind, P. E. (1949). Product of interaction between influenza virus enzyme and ovomucin. Nature, Lond. 164, 232.

Heimer, R. \& Meyer, K. (1956). Studies on sialic acids of submaxillary mucoid. Proc. Nat. Acad. Sci., Wash. 42, 728.

Holden, H. F. (1958). Apparatus for vacuum distillation and for 'freeze-drying.' Aust. J. exp. Biol. med. Sci. 36, 285.

Lineweaver, H. \& Burk, D. (1934). The determination of enzyme dissociation constants. J. Amer. chem. Soc. 56, 658.

Lowry, O. H., Rosebrough, N. J., Farr, A. L. \& Randall, R. J. (1951). Protein measurement with the Folin phenol reagent. J. biol. Chem. 193, 265.

Pye, J. \& Curtain, C. C. (1961). Electrophoretic, sedimentation and diffusion behaviour of crystalline neuraminidase from Vibrio cholerae. J. gen. Microbiol. 24, 423.

Reissig, J. L., Strominger, J. L. \& Lelorr, L. F. (1955). A modified colorimetric method for the estimation of $\mathrm{N}$-acetylamino sugars. J. biol. Chem. 217, 959.

Schramm, G. \& Mohr, E. (1959). Purification of neuraminidase from Vibrio cholerae. Nature, Lond. 183, 1677.

Tiselius, A., HJertén, S. \& Levin, Ö. (1956). Protein chromatography on calcium phosphate columns. Arch. Biochem. Biophys. 65, 132.

WARREN, L. (1959). The thiobarbituric acid assay of sialic acids. J. biol. Chem. 234, 1971. WERNER, I. \& ODIN, L. (1952). On the presence of sialic acid in certain glycoproteins and gangliosides. Acta. Soc. Med. upsalien. 57, 230.

\section{EXPLANATION OF PLATE}

Crystalline neuraminidase (phase contrast; $\times 300$ ). Photograph by Mr E. Matthaei. 